\title{
Advantages of extracurricular drama activities in foreign language teaching
}

\author{
M.V. Kuimova ${ }^{1}$, H. Uzunboylu ${ }^{2}$, D.A. Startseva ${ }^{1}$, K.P. Devyatova ${ }^{1}$ \\ ${ }^{1}$ National Research Tomsk Polytechnic University, Tomsk, Russia \\ mkuimova@mail.ru \\ ${ }^{2}$ Near East University, Nicosia, Turkey
}

\begin{abstract}
Culture is a very valuable part of society. The study of a foreign language not only teaches the language itself, but it also introduces information on another culture, moral values and attitudes. Improving the quality of foreign language education is important. Demanding course content, low proficiency and foreign language learning anxiety discourage students from learning. Difficulty in communicating in the target language reduces their selfconfidence. The use of drama could be one of the possible means to increase motivation and self-esteem and to improve foreign language skills and cultural awareness. The authors share their experience in using drama in extracurricular activities with students studying English as a foreign language at the Institute of Non-Destructive Testing, National Research Tomsk Polytechnic University.
\end{abstract}

Keywords: creative skills; dramatization; engineering education; extracurricular activity; foreign language teaching.

\section{Introduction}

There exist many approaches to meet the challenge of teaching English as a foreign language in a high school. In this paper we are going to research benefits of dramatization in extracurricular activities. Learning a foreign language favors learners' cognitive and thinking abilities, increases creativity and flexibility of mind [Ghonsooly \& Showqi, 2012; Kuimova, Burleigh \& Trofimova, 2016]. The use of literary works in L2 activities might become a source of pleasure for learners. Literary works are full of feelings, emotions, imagination and creativity. They demonstrate a rich and living language [Alemi, 2011]. Learners take advantage of being challenged with language that is slightly beyond their independent level of comprehension [Chen, 2014, Kuimova \& Karpacheva, 2016; Kuimova \& Ukhov, 2016].

\section{Related work}

Dramatization makes a valuable contribution to the understanding and appreciation of cultural diversity. It promotes students' abilities to learn and improves creativity [Kuimova \& Gaberling, 2014; Khabirovna \& Ruslanovna, 2015; Kuimova \& Polyushko, 2015]. Exciting environment of dramatization leads to learners' language improvement and facilitates creativity [Curtis, Howden, Curtis, McColm, Scrine, Blomfield, Reeve \& Ryan, 2013]. The use of music in drama activities helps create an emotionally warm, creative atmosphere [Kuimova \& Semchin, 2016]. Participation in dramatization furthers communication and writing abilities [Erdogan, 2013; Dundar, 2013].

\section{Findings and Discussion}

Dramatization is a creative use of writing and speaking on the basis of a literary work of art. It helps forward the full perception of literary works and the development of reproductive imagination as it involves penetration into the motives of the characters' actions, forwards tolerance and empathy. 
Additionally, researchers claim that the use of drama activities contributes to:

- promotion of learning motivation;

- motivation and enthusiasm in task performance;

- lowering language learning anxiety;

- development of para-verbal communication (intonation, stress, speed, pauses, etc.);

- development of voice control and speech-body synchrony;

- enhancement of speaking skills and confidence in verbal and non-verbal communication;

- language enrichment;

- inspiration to independent learning;

- development of creativity and critical thinking;

- enhancement of team-work skills;

- real world communication outside the classroom [Smith, 1984; Gassin, 1986; Davis, 1990; Gill, 1996; Omaggio Hadley, 2001; Giebert, 2013; Gjedde, 2013; Ahmad \& Juin, 2014; Bhat, 2014].

Drama and role-playing activities are powerful, valuable and rewarding teaching tools. They contextualize the language, enhance learners' emotional development, encourage creativity and imagination, and transfer the responsibility for learning from teacher to learners. Drama activities will be more successful and memorable if teacher promotes:

- positive environment;

- emotional involvement;

- collaborative and creative atmosphere;

- sense of achievement.

Dramatization can be profitable not only for an ESP (English for Special Purposes) classroom but also for engineering students whose future profession is not connected with theatre. It:

- develops social consciousness;

- stimulates intellectual development;

- enhances emotions and expressiveness in communication;

- develops critical and intuitive reasoning;

- betters interpersonal interaction;

- favors understanding and appreciation of foreign literature and culture.

The use of dramatization in extracurricular activities requires an elaborate preparation and thorough study of the chosen literary work. For dramatization we chose a brilliant comedy "The Importance of Being Earnest" by Oscar Wilde which is rich with epigrams and artful conversations.

The process of the comedy dramatization included three steps:

- preparation;

- dramatization;

- post-dramatization activities.

A group of nine second-year students of Institute of Non-Destructive Testing, National Research Tomsk Polytechnic University volunteered to stage the comedy for their peers. To begin with, we studied the comedy, found its short and adopted version and set the timetable for outclass rehearsals. Then we matched students with the comedy character list according to their personal attitude and preference. Afterwards, we started rehearsing, wherein we:

- studied cultural values in Great Britain in the late nineteenth century;

- eliminated linguistic difficulties (grammar and lexical) in the text; 
- mastered pronunciation and intonation;

- worked on mimics and body language;

- formed the image of the character.

The preparation took nearly three months. Before staging we also considered the costumes for our actors and drew backgrounds that were not costly or time-consuming, but could help the audience feel the atmosphere and mood of the nineteenth century in England.

After the performance, we decided to offer the audience a short quiz on the contents of the comedy. Following are the questions:

1) Where is Jack's house in the country?
a) Leicestershire
b) Hertfordshire
c) Worthing
d) Derbyshire

2) Where was Jack found as a baby? In a
a) carriage
b) handbag
c) park
d) suitcase

3) What do Gwendolen and Cecily require for their husbands?
a) they must be rich
b) they must be of noble birth
c) they must be well-educated
d) they must be named Ernest

4) Whom does Algernon ask to marry him?
a) Lady Bracknell
b) Miss Prism
c) Cecily Cardew
d) Gwendolen Fairfax

5) What is the name of Algernon's imaginary friend?
a) Avery
b) Bunbury
c) Timothy
d) Humphrey

6) What does the name Ernest mean to Gwendolen? It inspires
a) confidence
b) love
c) respect
d) loyalty

7) What does Cecily offer Gwendolen to drink?
a) coffee
b) milk
c) fruit drink
d) tea

8) Why does Lady Bracknell object to Jack's courtship to Gwendolen? She dislikes his
a) political views
b) smoking
c) origin
d) financial status 
Answers:1 - b; 2-b;3-d;4-c;5-b;6-a;7-d;8-c.

Finally, the audience was given the task to write an essay of maximum 250 words on the topic: "What is the difference between the ideas of marriage during the Victorian era and our time?". The essay was to be written at home and brought for the next lesson.

The students who participated in the comedy dramatization were delighted with the audience support and approval. On the whole, they outlined the following advantages of the accomplished work; it helped to:

- motivate further language study;

- develop confidence in foreign language speaking;

- improve speaking skills;

- develop artistic skills;

- improve cultural awareness.

\section{Conclusion}

Thus, drama activities give not only fun to learners, but also provide a wide-range of oral interaction to practice the target language. They bring in creative elements in language learning, develop a "feel" of the language under study, deepen learners' understanding of another culture and raise self-confidence and a good self-image. Dramatization has a significant value in developing communicative competence and public speaking, teaching to think on their feet, developing body language and helping to be persuasive in a foreign language.

\section{References}

Ghonsooly, B. \& Showqi, S. (2012). The effects of foreign language learning on creativity. English Language Teaching, Volume 5, Issue 4, pp. 161-167.

Kuimova, M., Burleigh, D. \& Trofimova, A. (2016). Problem-based teaching in engineering education. MATEC Web of Conferences, Volume 48. 5p. DOI http://dx.doi.org/10.1051/matecconf/20164806006

Alemi, M. (2011). The use of literary works in an EFL class. Theory and Practice in Language Studies, Volume 1, Issue 2, pp. 177-180.

Chen, M.-L. (2014). Teaching English as a foreign language through literature. Theory and Practice in Language Studies, Volume 4, Issue 2, pp. 232-236.

Kuimova, M.V. \& Karpacheva, E.V. (2016). Game as a Means to Enhance Foreign Language Teaching. Ponte, Volume 72, Issue 2, pp. 14-17.

Kuimova, M.V. \& Ukhov, S.A. (2016). Some Benefits of Extracurricular Reading in Foreign Language Teaching. Ponte, Volume 72, Issue 4, pp. 276-280.

Kuimova, M.V. \& Gaberling, I.P. (2014). Drama in extracurricular activities for technical university students studying English as a foreign language. Life Science Journal, Volume 11, Issue 9, pp. 352-353.

Khabirovna, S.L. \& Ruslanovna, M.L. (2015). Technology of dramatization as a creative method of teaching English as a foreign language (By an example of a special course "English Theatre"). Mediterranean Journal of Social Sciences, Volume 6, Issue 3, pp. 296-300.

Kuimova, M.V. \& Polyushko, D.A. (2015). Dramatization at extracurricular activities as a means to enhance foreign language teaching. International Journal of Emerging Technologies in Learning (iJET), Volume 10, Issue 1, pp. 72-73.

Curtis, D.J., Howden, M., Curtis, F., McColm, I., Scrine, J., Blomfield, T., Reeve, I., \& Ryan, T. (2013). Drama and environment: Joining forces to engage children and young people in 
environmental education. Australian Journal of Environmental Education, Volume 29, Issue 2, pp. 182-201.

Kuimova, M.V. \& Semchin, E.A. (2016). Some Benefits of Extracurricular Musical Education for Primary Schoolchildren. Ponte, Volume 72, Issue 2, pp. 60-64.

Erdogan, T. (2013). The effect of creative drama method on pre-service classroom teachers' writing skills and attitudes towards writing. Australian Journal of Teacher Education, Volume 38, Issue 1, pp. 45-61.

Dundar, S. (2013). Nine drama activities for foreign language classrooms: Benefits and challenges. Procedia - Social and Behavioral Sciences, Volume 70, pp. 1424-1431.

Smith, S.M. (1984). The theatre arts and the teaching of second languages. Massachusetts: Addison Wesley Longman Publishing Co, $170 \mathrm{p}$.

Gassin, J. (1986). Drama and the advanced ESL learner: An integrated approach to communication skills. ARAL Series, Volume 3, pp. 57-68.

Davis, P. (1990). The use of drama in English language teaching. TESL Canada Journal, Volume 8, Issue 1, pp. 87-99.

Gill, C. (1996). Using drama techniques to encourage oral interaction. The English Teacher, Volume 25, pp. 72-86.

Omaggio Hadley, A. (2001). Teaching Language in Context. Heinle \& Heinle; 3rd edition. $512 \mathrm{p}$.

Giebert, S. (2014). Drama and theatre in teaching foreign languages for professional purposes. Reaching and Teaching Languages for Professional Purposes, Volume XXXIII, Issue 1, pp. $138-150$.

Gjedde, L. (2013). Role game playing as a platform for creative and collaborative learning. 7th European Conference on Games Based Learning, ECGBL 2013, Volume 1, pp. 190-197. Ahmad, A.E. \& Juin, L.S. (2014). Developing students' creative response to literary texts in the ESL classroom. Pertanika Journal of Social Science and Humanities, Volume 22, Issue 3, pp. 763-774.

Bhat, A.Z. (2014). Inspiring creative minds. Lecture Notes in Electrical Engineering, Volume 247 LNEE, pp. 483-496. 